\title{
THE RELATIVE SUSCEPTIBILITY AND MONITORING OF CITRUS / VARIETIES TO THE FLATHEADED BORER PTOSIMA UNDECIMMACU LATA HERBST (COLEOPTERA: BUPRESTIDAE) IN CITRUS ORCHARDS
}

\author{
HASHIM, S. M., R. M. ABD EL-MOATY and A. W. TADROS \\ Plant Protection Research Institute, Agric. Res. Center, MOA, Giza, Egypt. \\ (Manuscript received 22 February 2018)
}

\begin{abstract}
$\mathrm{T}$ he relative susceptibility and monitoring of nine widely spread citrus / varieties: Navel orange, Balady orange, Valencia orange, grape-fruit, Balady Mandarin, lime, Lemon, Sour orange and Volkamer lemon to Ptosima undecimmaculata (Coleoptera: Buprestidae) borer infestation as well as the population fluctuation were studied at Sharkia governorate, during the three successive years 2015, 2016 and 2017. The mean rate of susceptibility of citrus species and varieties to $P$. undecimmaculata infestation reached $16.3 \%$ (range, $2-46 \%$ ). The grand mean degree of susceptibility of citrus species / varieties to $P$. undecimmaculata infestation approximated 0.377 beetles / tree / year. Infestation increased from 0.341 beetles / tree at the end of 2015 (one year), to 0.720 beetles / tree at the end of 2016 (two years) to 1.331 beetles / tree at the end of 2017 (three years). Summer months recorded the maximum beetle flight $(0.242$ beetles), followed by spring ( 0.077 beetle) or autumn months ( 0.058 beetles) /tree, and stopped during winter. The grand mean degree of susceptibility of citrus species / varieties to $P$. undecimmaculata infestation approximated 0.094 beetles / tree / season. Generally, Navel orange (19.1\%) and Valencia orange (17.2\%) were the most susceptible species followed descending by Balady orang $(14.3 \%)$, Grape fruit, (13.8\%) Mandarin (13.8\%), Volkamer Lemon $(10.3 \%)$, while the least were Sour orange (6.4\%), Lime (4.5\%) and Lemon (2.4\%).
\end{abstract}

\section{INTRODUCTION}

Citrus are the most favorite and popular fruits; as well as are the most economic exporting crop. Therefore in Egypt, citrus rank first in fruit area and production and several citrus species and varieties are spread all-over Egyptian zones to increase the harvesting period and accommodate local consumption and exportation. The most widely spread citrus / varieties are Navel orange (Citrus sinensis), Balady orange ( $C$. sinensis), Valencia orange ( $C$. sinensis), grape-fruit ( $C$. paradisi), Mandarin (C. reticulata), lime ( $C$. aurantifolia), Lemon ( $C$. limon), Sour orange ( $C$. aurantium) and Volkamer lemon ( $C$. volkameriana).

$P$. undecimmaculata stem borer is widely distributed all-over the Mediterranean basin area. All-over the governorates of Egypt, $P$. undecimmaculata attack citrus orchards (Hashim et al. 2017) well as different fruit tree hosts such as mango 
(Hashim and Ahmed, 2011), apricot (Kinawy et al., 1992 and Tadros et al., 2006-a), peach, plum, almond, etc. (Batt, 1999 and Hashim, 2009). Larvae live and feed in a shallow tunnels under the bark of tree stem and main branches and cause girdling the wood, weakness, reducing the production, and finally their death. The total life cycle was completed in an almost one year

Citrus trees also are attacked by several Coleopteran stem borers such as the cerambycids Chlorophorus varius (Tadros, 1993), Macrotoma palmata (Tadros et al., 1993), Scolytus amygdale (Tadros, 1994), the Bostrichid Enneadesmus obtusedentatus (Tadros et al., 1997), as well as the Lepidopterous cossid Paropta paradoxa (El-Assal et al., 2008).

Studies on the rate and degree of infestation, seasonal fluctuation of the target pest population, the progress of infestation, the seasonal cycle, and the effect of the main weather factors is essential in successful integrated pest control. However, the literature on the relative susceptibility of citrus species and varieties to borer's infestation is lacking allover the world and in Egypt.

The present study is an attempt to contribute such a gap in the knowledge on the population fluctuation and the relative susceptibility of citrus tree borers to different citrus species and varieties. The broad objective of investigation is to add a new information that may help in planning citrus structure system, choice of economic species and varieties and effective "Integrated Control Programs" for the management of tree borers in citrus orchards (Tadros et al., 2006-b).

\section{MATERIALS AND METHODS}

The relative susceptibility of the following nine citrus species and varieties, Navel orange, Balady orange, Valencia orange, grape-fruit, Mandarin (Balady), lime, Lemon, Sour orange (Naring) and Volkamer lemon to $P$. undecimmaculata borer infestation were subjected to the present study.

Infestation studies (rate and degree) of the target borer P. undecimmaculata were carried out during the three successive seasons 2015, 2016 and 2017 in citrus orchards spread all-over about 100 feddans area (more than 25 years old) located at Wadi El-Mollak district, Sharkia governorate.

\section{Rate of Infestation:}

The rate of infestation was assessed by the percentage of numbers of infested trees with $P$. undecimmaculata in each citrus species / variety randomly distributed in the considered citrus orchards each year.

\section{Degree of Infestation:}

The degree of infestation was estimated by the mean number of adult beetles per tree (indicated by the exit holes) that completed their life cycle and emerged from 
each citrus species / variety in the considered random citrus orchards each year four times at the end of each season (winter, spring, summer and autumn). At the end of each season, the old counted exit holes were canceled by spray paint.

\section{Progress of infestation:}

Data of the degree of infestation were accumulated from January 1st 2015 until January 1st 2017 for each year. The total number of adults represented the accumulated number for the three years together. Progress of infestation indicated the rate of increase in the borer infestation year after another.

\section{RESULTS AND DISCUSSION}

\section{Rate of $\boldsymbol{P}$. undecimmaculata Infestation:}

Data presented in table (1) showed thatThe rate of $P$. undecimmaculata infestation which varied from one citrus / varieties to another. Navel orange was the highest susceptible species to the borer infestation showing $23-46 \%$, with a mean of $33 \%$, and Valencia orange showing $15-39 \%$, with a mean of $24.7 \%$, Ballady orange ranging $13-35 \%$, with a mean of $51.3 \%$ infestation, and Grape fruit ranging 12 $32 \%$, with a mean of $23 \%$, Mandarin ranging $11-21 \%$, with a mean of $16.7 \%$. The moderately and least susceptible were Volkamer lemon ( $8-14 \%$, with a mean of $10.7 \%)$, Sour orange $(6-9 \%$, with a mean of $7.7 \%)$, and last Lime $(1-10 \%$, with a mean of $5.3 \%)$, and lemon ( $2-5 \%$, with a mean of $3.3 \%$ ).

The general mean percent of $P$. undecimmaculata infestation in citrus (species / varieties) orchards ranged from $13.9-17.8 \%$, with a grand mean of $16.3 \%$.

Table 1. Rate of $P$. undecimmaculata infestation in citrus species / varieties, Navel orange, Balady orange, Valencia orange, grape fruit, Mandarin, lime, Lemon, Sour orange and Volkamer lemon at Sharkia governorate during 2015, 2016 and 1017 activity seasons.

\begin{tabular}{|c|c|c|c|c|c|}
\hline \multirow{2}{*}{ No. } & \multirow{2}{*}{ Variety } & \multicolumn{4}{|c|}{ Rate of infestation (\%) } \\
\hline & & 2015 & 2016 & 2017 & Mean \\
\hline 1 & Navel orange & 23 & 30 & 46 & 33 \\
\hline 2 & Ballady orange & 35 & 13 & 19 & 22.3 \\
\hline 3 & Valencia orange & 39 & 15 & 20 & 24.7 \\
\hline 4 & Grape fruit & 12 & 32 & 25 & 23 \\
\hline 5 & Mandarin & 21 & 11 & 18 & 16.7 \\
\hline 6 & Lime & 1 & 5 & 10 & 5.3 \\
\hline 7 & Lemon & 5 & 3 & 2 & 3.3 \\
\hline 8 & Sour orange & 9 & 8 & 6 & 7.7 \\
\hline 9 & Volkamer lemon & 10 & 8 & 14 & 10.7 \\
\hline \multicolumn{2}{|c|}{ Total } & 155 & 125 & 160 & 146.7 \\
\hline \multicolumn{2}{|c|}{ Mean / species or variety } & 17.2 & 13.9 & 17.8 & 16.3 \\
\hline
\end{tabular}




\section{The degree of $P$. undecimmaculata infestation and seasonal activity:}

The degree of $P$. undecimmaculata infestation and seasonal activity showed obvious variation between different citrus species / varieties (Tables 2, 3 and 4).

\subsection{Navel orange:}

It was the highly susceptible citrus species as the mean number of holes / tree approximated $0.55,0.61$ and 0.72 holes (emerged beetles) / tree / year during the three years of study 2015, 2016 and 2017, respectively. The respective degrees of infestation / month were 0.046, 0.05 and 0.06 holes / tree. Summer months showed the mean number of beetles, 33, 35 and 40 holes (emerged beetles) / tree during the three years 2015, 2016 and 2017, respectively. Spring months showed less mean number of emerged beetles, 12, 15 and 18 holes (emerged beetles) / tree during the respective three years. Autumn months were the least mean numbers of emerged beetles (holes) / tree were 10, 11 and 14 holes / tree during the respective three years. Beetles stopped emergence during winter months. The grand means of emerged beetles / tree / season were $0.14,0.15$ and 0.18 holes during the respective three years.

\subsection{Valencia orange:}

Was also highly susceptible citrus species as the mean number of holes / tree approximated $0.5,0.56$ and 0.65 holes (emerged beetles) / tree / year during the three years of study 2015, 2016 and 2017, respectively. The respective degrees of infestation / month were $0.04,0.05$ and 0.05 holes / tree.

Summer months showed the mean number of emerged beetles, 31, 34 and 38 holes (emerged beetles) / tree during the three years 2015, 2016 and 2017, respectively. Spring months showed less mean number of emerged beetles, 10, 12 and 15 holes (emerged beetles) / tree during the respective three years. Autumn months showed same mean numbers of emerged beetles (holes) / tree were 9, 10 and 12 holes / tree during the respective three years. Beetles stopped emergence during winter months. The grand means of emerged beetles / tree / season were $0.14,0.14$ and 0.16 holes during the respective three years.

\subsection{Ballady orange:}

Data proved that, ballady orange was highly susceptible citrus species as the mean number of holes / tree approximated 0.45, 0.48 and 0.54 holes (emerged beetles) / tree / year during the three years of study 2015, 2016 and 2017, respectively. The respective degrees of infestation / month were $0.0375,0.04$ and 0.045 holes / tree. Summer months showed the mean number of emerged beetles, 29, 30 and 33 holes (emerged beetles) / tree during the three years 2015, 2016 and 2017, respectively. Spring months showed less mean number of emerged beetles, 9, 
10 and 12 holes (emerged beetles) / tree during the respective three years. Autumn months were also the same mean numbers of emerged beetles (holes) / tree were 7, 8 and 9 holes / tree during the respective three years. Beetles stopped emergence during winter months. The grand means of emerged beetles / tree / season were $0.11,0.12$ and 0.135 holes during the respective three years.

\subsection{Grape fruit:}

It was the relatively highly susceptible citrus species as the mean number of holes / tree approximated 0.48, 0.49 and 0.52 holes (emerged beetles) / tree / year during the three years of study 2015, 2016 and 2017, respectively. The respective degrees of infestation / month were $0.04,0.041$ and 0.043 holes / tree. Summer months showed the mean number of emerged beetles, 34, 35 and 35 holes (emerged beetles) / tree during the three years 2015, 2016 and 2017, respectively. Spring months showed less mean number of emerged beetles, 8, 9 and 11 holes (emerged beetles) / tree during the respective three years. Autumn months were the same mean numbers of emerged beetles (holes) / tree were 6, 5 and 6 holes / tree during the respective three years. Beetles stopped emergence during winter months. The grand means of emerged beetles / tree / season were $0.12,0.1225$ and 0.13 holes during the respective three years.

\subsection{Mandarin (Balady):}

Mandarin (balady) species showed the highly susceptible one as the mean number of holes / tree approximated 0.41, 0.46 and 0.52 holes (emerged beetles) / tree / year during the three years of study 2015, 2016 and 2017, respectively. The respective degrees / of infestation month were $0.033,0.038$ and 0.043 holes / tree. Summer months showed the mean number of emerged beetles, 28, 30 and 32 holes (emerged beetles) / tree during the three years 2015, 2016 and 2017, respectively. Spring months showed less mean number of emerged beetles, 8, 10 and 10 holes (emerged beetles) / tree during the respective three years. Autumn months were the least mean numbers of emerged beetles (holes) / tree were 5, 6 and 8 holes / tree during the respective three years. Beetles stopped emergence during winter months. The grand means of emerged beetles / tree / month were $0.10,0.115$ and 0.13 holes during the respective three years.

\subsection{Volkamer lemon:}

It was less susceptible citrus species as the mean number of holes / tree approximated $0.29,0.33$ and 0.39 holes (emerged beetles) / tree / year during the three years of study 2015, 2016 and 2017, respectively. The respective degrees of infestation / month were $0.024,0.027$ and 0.032 holes / tree. Summer months showed the mean number of emerged beetles, 20, 21 and 24 holes (emerged beetles) / tree during the three years 2015, 2016 and 2017, respectively. Spring months showed less 
mean number of emerged beetles, 6, 7 and 8 holes (emerged beetles) / tree during the respective three years. Autumn months were the least mean numbers of emerged beetles (holes) / tree were 3, 5 and 7 holes / tree during the respective three years. Beetles stopped emergence during winter months. The grand means of emerged beetles / tree / season were $0.07,0.08$ and 0.097 holes during the respective three years.

\subsection{Sour orange (Naring):}

This species was the lower susceptible when compared with aforementioned citrus species as the mean number of holes / tree approximated $0.19,0.21$ and 0.24 holes (emerged beetles) / tree / year during the three years of study 2015, 2016 and 2017, respectively. The respective degrees of infestation / month were $0.016,0.017$ and 0.02 holes / tree. Summer months showed the mean number of emerged beetles, 14, 15 and 17 holes (emerged beetles) / tree during the three years 2015, 2016 and 2017, respectively. Autumn months were the least mean numbers of emerged beetles (holes) / tree were 2, 3 and 2 holes / tree during the respective three years. Spring months showed less mean number of emerged beetles, 3, 3 and 5 holes (emerged beetles) / tree during the respective three years. Beetles stopped emergence during winter months. The grand means of emerged beetles / tree / season were 0.05, 0.05 and 0.06 holes during the respective three years.

\subsection{Lime :}

It was much low susceptible citrus species as the mean number of holes / tree approximated $0.13,0.15$ and 0.17 holes (emerged beetles) / tree / year during the three years of study 2015, 2016 and 2017, respectively. The respective degrees of infestation / month were $0.01,0.012$ and 0.014 holes / tree. Summer months showed the mean number of emerged beetles, 10, 11 and 12 holes (emerged beetles) / tree during the three years 2015, 2016 and 2017, respectively. Autumn months were the least mean numbers of emerged beetles (holes) / tree were 1, 2 and 3 holes / tree during the respective three years. Spring months showed less mean number of emerged beetles, 2, 2 and 2 holes (emerged beetles) / tree during the respective three years. Beetles stopped emergence during winter months. The grand means of emerged beetles / tree / season were 0.03, 0.037 and 0.037 holes during the respective three years.

\subsection{Lemon:}

This citrus species was the least susceptible as the mean number of holes / tree approximated 0.06, 0.08 and 0.49 holes (emerged beetles) / tree / year during the three years of study 2015, 2016 and 2017, respectively. The respective degrees of infestation / month were 0.005, 0.007 and 0.008 holes / tree. Summer months showed the mean number of emerged beetles, 5, 6 and 7 holes (emerged beetles) / 
tree during the three years 2010, 2011 and 2012, respectively. Autumn months were the least mean numbers of emerged beetles (holes) / tree were 0, 8 and 1 holes / tree during the respective three years. Spring months showed less mean number of emerged beetles, 1, 1 and 1 holes (emerged beetles) / tree during the respective three years. Beetles stopped emergence during winter months. The grand means of emerged beetles / tree / season were $0.015,0.02$ and 0.022 holes during the respective three years.

Table 2. Mean number of $P$. undecimmaculata beetles in Navel orange (Nav), Balady orange (Bal), Valencia orange (Val), Grape-fruit (G-f), Mandarin (Man), Lime (Lim), Lemon (Lem), Sour orange (S-o) and Volkamer Lemon (V-m) in citrus orchards, at Sharkia governorate during 2015 activity seasons.

\begin{tabular}{|c|c|c|c|c|c|c|c|c|c|c|}
\hline \multirow{2}{*}{$\begin{array}{l}\text { Date of } \\
\text { inspection }\end{array}$} & \multicolumn{10}{|c|}{ Mean no. of beetles $\backslash 100$ trees } \\
\hline & Nav & Bal & Val & $G-f$ & Mnd & Lim & Lem & S-o & $V-m$ & Mean \\
\hline $\begin{array}{l}\text { Winter } \\
\text { (Jan. - Mar.) }\end{array}$ & 0 & 0 & 0 & 0 & 0 & 0 & 0 & 0 & 0 & 0 \\
\hline $\begin{array}{l}\text { Spring } \\
\text { (Apr. - Jun.) }\end{array}$ & 12 & 9 & 10 & 8 & 8 & 2 & 1 & 3 & 6 & 6.555 \\
\hline $\begin{array}{l}\text { Summer } \\
\text { (Jul. - Sept.) }\end{array}$ & 33 & 29 & 31 & 34 & 28 & 10 & 5 & 14 & 20 & 22.666 \\
\hline $\begin{array}{l}\text { Autumn } \\
\text { (Oct. - Dec.) }\end{array}$ & 10 & 7 & 9 & 6 & 5 & 1 & 0 & 2 & 3 & 4.777 \\
\hline Grand Total (GM) & 55 & 45 & 50 & 48 & 41 & 13 & 6 & 19 & 29 & 33.998 \\
\hline GM/tree/year & 0.55 & 0.45 & 0.5 & 0.48 & 0.41 & 0.13 & 0.06 & 0.19 & 0.29 & 0.34 \\
\hline GM / tree/ season & 0.14 & 0.11 & 0.125 & 0.12 & 0.10 & 0.03 & 0.015 & 0.05 & 0.047 & 0.085 \\
\hline GM / tree/ month & 0.05 & 0.037 & 0.04 & 0.04 & 0.033 & 0.01 & 0.005 & 0.016 & 0.024 & 0.0283 \\
\hline
\end{tabular}

Table 3. Mean number of $P$. undecimmaculata beetles in Navel orange (Nav), Balady orange (Bal), Valencia orange (Val), Grape-fruit (G-f), Mandarin (Man), Lime (Lim), Lemon (Lem), Sour orange (S-o) and Volkamer Lemon (V-m) in citrus orchards, at Sharkia governorate during 2016 activity seasons.

\begin{tabular}{|c|c|c|c|c|c|c|c|c|c|c|}
\hline \multirow{2}{*}{$\begin{array}{c}\text { Date of } \\
\text { inspection }\end{array}$} & \multicolumn{9}{|c|}{ Mean no. of beetles $\backslash 100$ trees } \\
\cline { 2 - 11 } & Nav & Bal & Val & G-f & Mnd & Lim & Lem & S-o & V-m & Mean \\
\hline $\begin{array}{c}\text { Winter } \\
\text { (Jan. - Mar.) }\end{array}$ & 0 & 0 & 0 & 0 & 0 & 0 & 0 & 0 & 0 & 0 \\
\hline $\begin{array}{c}\text { Spring } \\
\text { (Apr. - Jun.) }\end{array}$ & 15 & 10 & 12 & 9 & 10 & 2 & 1 & 3 & 8 & 7.777 \\
\hline $\begin{array}{c}\text { Summer } \\
\text { (Jul. - Sept.) }\end{array}$ & 35 & 30 & 34 & 35 & 30 & 11 & 6 & 15 & 24 & 24.44 \\
\hline $\begin{array}{c}\text { Autumn } \\
\text { (Oct. - Dec.) }\end{array}$ & 11 & 8 & 10 & 5 & 6 & 2 & 1 & 3 & 5 & 5.666 \\
\hline \begin{tabular}{c} 
Grand Total (GM) \\
\hline GM / tree/year
\end{tabular} & 61 & 48 & 56 & 49 & 46 & 15 & 8 & 21 & 33 & 37.88 \\
\hline GM / tree/ season & 0.15 & 0.12 & 0.14 & 0.12 & 0.115 & 0.037 & 0.02 & 0.05 & 0.08 & 0.095 \\
\hline \begin{tabular}{c} 
GM / tree/ month \\
\hline
\end{tabular} & 0.05 & 0.04 & 0.05 & 0.04 & 0.038 & 0.012 & 0.007 & 0.017 & 0.027 & 0.032 \\
\hline
\end{tabular}


Table 4. Mean number of $P$. undecimmaculata beetles in Navel orange (Nav), Balady orange (Bal), Valencia orange (Val), Grape-fruit (G-f), Mandarin (Man), Lime (Lim), Lemon (Lem), Sour orange (S-o) and Volkamer Lemon (V-m) in citrus orchards, at Sharkia governorate during 2017 activity seasons.

\begin{tabular}{|c|c|c|c|c|c|c|c|c|c|c|}
\hline \multirow{2}{*}{$\begin{array}{c}\text { Date of } \\
\text { inspection }\end{array}$} & \multicolumn{9}{|c|}{ Mean no. of beetles $\backslash 100$ trees } \\
\cline { 2 - 11 } & Nav & Bal & Val & G-f & Mnd & Lim & Lem & S-o & V-m & Mean \\
\hline $\begin{array}{c}\text { Winter } \\
\text { (Jan. - Mar.) }\end{array}$ & 0 & 0 & 0 & 0 & 0 & 0 & 0 & 0 & 0 & 0 \\
\hline $\begin{array}{c}\text { Spring } \\
\text { (Apr. - Jun.) }\end{array}$ & 18 & 12 & 15 & 11 & 12 & 2 & 1 & 5 & 3 & $\mathbf{8 . 7 7}$ \\
\hline $\begin{array}{c}\text { Summer } \\
\text { (Jul. - Sept.) }\end{array}$ & 40 & 33 & 38 & 35 & 32 & 12 & 7 & 17 & 15 & 25.44 \\
\hline $\begin{array}{c}\text { Autumn } \\
\text { (Oct. - Dec.) }\end{array}$ & 14 & 9 & 12 & 6 & 8 & 3 & 1 & 2 & 7 & 6.88 \\
\hline Grand Total (GM) & 72 & 54 & 65 & 52 & 52 & 17 & 9 & 24 & 39 & 41.09 \\
\hline GM / tree/year & 0.72 & 0.54 & 0.65 & 0.52 & 0.52 & 0.17 & 0.09 & 0.24 & 0.39 & 0.411 \\
\hline GM / tree/ season & 0.18 & 0.135 & 0.16 & 0.13 & 0.13 & 0.04 & 0.022 & 0.06 & 0.097 & 0.103 \\
\hline GM / tree/ month & 0.06 & 0.045 & 0.05 & 0.043 & 0.043 & 0.014 & 0.008 & 0.02 & 0.032 & 0.034 \\
\hline
\end{tabular}

Table 5. Progressive mean number of $P$. undecimmaculata beetles in citrus (in Navel orange, Balady orange, Valencia orange, Grape-fruit, Mandarin, Lime, Lemon, Sour orange and Volkamer Lemon) orchards, at Sharkia governorate during 2015, 2016 and 2017 activity seasons.

\begin{tabular}{|c|c|c|c|c|c|}
\hline \multirow{2}{*}{$\begin{array}{c}\text { Date of } \\
\text { inspection }\end{array}$} & \multicolumn{5}{|c|}{ Mean no. of beetles $\backslash$ trees } \\
\cline { 2 - 6 } & 2015 & 2016 & $\begin{array}{c}\text { Sum of two } \\
\text { successive years }\end{array}$ & 2017 & $\begin{array}{c}\text { Sum of three } \\
\text { successive years }\end{array}$ \\
\hline $\begin{array}{c}\text { Winter } \\
\text { (Jan. - Mar.) }\end{array}$ & 0 & 0 & 0 & 0 & 0 \\
\hline $\begin{array}{c}\text { Spring } \\
\text { (Apr. - Jun.) }\end{array}$ & 0.066 & 0.078 & 0.144 & $\mathbf{0 . 0 8 8}$ & 0.232 \\
\hline $\begin{array}{c}\text { Summer } \\
\text { (Jul. - Sept.) }\end{array}$ & 0.227 & 0.244 & 0.471 & 0.254 & 0.725 \\
\hline $\begin{array}{c}\text { Autumn } \\
\text { (Oct. - Dec.) }\end{array}$ & 0.048 & 0.057 & 0.105 & 0.069 & 0.174 \\
\hline GM / tree/year & 0.341 & 0.379 & 0.720 & 0.411 & 1.131 \\
\hline GM / tree/ season & 0.085 & 0.095 & 0.180 & 0.103 & 0.283 \\
\hline GM / tree/ month & 0.028 & 0.032 & 0.060 & 0.034 & 0.094 \\
\hline
\end{tabular}

\section{Progress of infestation:}

Infestation with P. undecimmaculata in citrus species / varieties (Navel orange, Balady orange, Valencia orange, Grape fruit, Mandarin, Lime, Lemon, Sour orange and Volkamer Lemon) increased from one year to another (Table, 5). Generally, infestation increased from 0.341 beetles in 2015 to 0.379 beetles in 2016 to 0.411 beetles (expressed by exit holes) / tree at the end of 2017. Thus infestation almost doubled after one year $(0.720)$ and increased three times at the end of the third year showing 1.131 beetles / tree / year. This rapid increase impose the urgent need of control.

\section{Discussion and conclusion:}

P. undecimmaculata attacks several fruit species mainly apricot, peach, plum, almond, apple and pear (Kinawy et al., 1992). Citrus orchards are also subjected to $P$. 
undecimmaculata infestation (Hashim et al., under publication) as well as other fruit tree borers such as Chlorophorus varius, Macrotoma palmata, Hypothenemus eruditus, and Paropta paradoxa (El-Assal et al., 2008). The current study is unique in determining the relative difference in the susceptibility of local and established foreign citrus species / varieties to the target borer infestation.

Monitoring studies (especially the seasonal fluctuation of insect pest population, progress of infestation, seasonal cycle, and effect of the main weather factors on the target pests) are essential in planning successful and effective "Integrated Control Programs" for the management of boring insect pest. Citrus / varieties showed variable rates of $P$. undecimmaculata infestation. Navel orange was the highest rate (33\% infested trees), followed by Valencia orange, Grape fruit, Ballady orange, Mandarin, and Volkamer lemon (24.7, 23, 22.3, 16.7, and 10.7\% infested trees, respectively). The least rate were Sour orange, Lime and Lemon (7.7, 5.3 , and $3.3 \%$ infested trees, respectively). The grand mean rate of infestation was (16.3\% infested trees).

The progress of infestation data confirmed that $P$. undecimmaculata infestation almost doubled after each one single year, infestation will seriously multiple in few years especially in navel orange ( 0.72 beetles / tree / year) and Valencia orang ( 0.65 beetles / tree / year). Balady orange, Mandarin, and Grape fruit, were also threatened (54, 52 and 52 beetles / tree / year, respectively). Volkamer Lemon was moderately attacked ( 0.39 beetles / tree / year), while the least susceptible species were Sour orange ( 0.24 beetles / tree / year) and Lime and Lemon species (17 and 9 beetles / tree / year, respectively), similar rank of citrus species susceptibility was recorded by Hashim et al. 2014 for the peach tree borer Chlorophorus varius. According to 2017 season, summer months recorded the maximum beetle flight $(0.07-0.40$, with a mean of 0.2544 beetles/ tree / year), followed by spring $(0.01-0.18$, with a mean of 0.0877 beetles/ tree / year), or autumn months $(0.01-0.14$, with a mean of 0.0688 beetles/ tree / year), /tree, but flight stopped during winter, similar flight beetles activity was recorded by Hashim and Ahmed 2011 for $P$. undecimmaculata in mango orchards. These rates and degrees of $P$. undecimmaculata infestation impose the need to control this pest in citrus orchards, especially in Navel orange, Balady orange, Valencia orange, Grape fruit, Mandarin, and Lemon orchards.

\section{REFERENCES}

1. Batt, A. M. 1999. Survey of borers attacking deciduous fruit trees in Egypt with reference to certain biological and ecological studies. Egyptian J. of Agric. Res., 77 (3): 1081-1102. 
2. El-Assal, M.M.A., M.M. Abdel-Azim and A.W. Tadros. 2008. Monitoring the solitary carpenter worm, Paropta paradoxa (Lepidoptera: Cossidae), recently serious pest in mandarin orchards in Egypt. Egypt. J. Agric. Res., Cairo, Egypt, 17 Feb., 2008.

3. Hashim, S. M. 2009. Ecological and Control Studies on Mango Tree Borers and Their Natural Enemies in Egypt. Ph D Thesis, Faculty of Science, Cairo University.

4. Hashim, S. M., Abd El-Moaty, R. M., and Tadros, A.W. (under publication): Monitoring Ptosima undecimmaculata Herbst (Coleoptera: Buprestidae) in orange orchards in Egypt. Egypt. J. Agric. Res., Cairo, Egypt, in PRESS

5. Hashim, S. M. and Ahmed, H.M. 2011. Population fluctuation of the metalic Beetle Ptosima undecimmaculata (HERBEST) (Coleoptera: Buprestidae) in Mango Orchards. Bull.Ent.Soc. Egypt, 88, 2011(169 - 177).

6. Hashim, S. M., A. W. Tadros and Eman A. Abdel Hamid. 2014. The relative susceptibility and monitoring of citrus species varieties to Chlorophorus varius in citrus orchards in Egypt. J. Agric. Res., 92 (1): 9- 19.

7. Kinawy, M. M.; F. F. Abd-Allah and A. W. Tadros. 1992. Seasonal abundance of the plum woodborer, Ptosima undecimmaculata Herbst (Coleoptera: Buprestidae) on apricot in Egypt. Communications in Science and Development Research, Alexandria, Egypt, 40 (496): 231-242.

8. Tadros, A.W. 1993. The life cycle of the wasp beetle, Chlorophorus varius Mull. (Coleoptera: Cerambycidae) on peach in Egypt. Egypt. J. Agric. Res., 71 (2): 429435.

9. Tadros, A.W. 1994. Monitoring the population of the shot-hole bark-beetle, Scolytus amygdali Guer. (Coleoptera: Scolytidae) on peach and its hosts in Egypt. Egypt. J. Agric. Res., 72 (1): 91-102.

10. Tadros, A.W., A. M. Abdel-Rahman and I. A. Abdel-Hamid (2006-a): Stone Fruit Pests: (5) Monitoring the major apricot tree borers (Ptosima undecimmaculata, Chlorophorus varius, Macrotoma palmata and Scolytus amygdali (Col.: Scolytidae) in Egypt. Egypt. J. Agric. Res., Egypt, 84 (6): 1789-1809.

11. Tadros, A.W., A. M. Abdel-Rahman and I. A. Abdel-Hamid. (2006-b): Stone Fruit Pests: (6) Alternative means of control of Ptosima undecimmaculata by horticultural, mechanical, microbiological and local chemical treatments in apricot orchards in Egypt. Egypt. J. Agric. Res., Egypt, Feb 19th, 2006.

12. Tadros, A.W.; M.M. Kinawy and F.F. Abd-Allah. 1993. Population dynamics and host range of Macrotoma palmata F. (Coleoptera: Cerambycidae). Insect Science and its Application, Nairobi, Kenya, 14 (5 - 6): 246-354.

13. Tadros, A.W., A.M. Semeada; S.I. El-Sherif and A.A. Fattouh. 1997. Survey of the insect pests in vineyards in Egypt. 7th Nat. Conf. of Pest \& Dis. of Vegetables \& fruits in Egypt, 1997: 242-249. 
الحساسية النسبية لإصابة أهم أصناف / المو الح بحفار ساق البرقوق مبططة الرأس

Ptosima undecimmaculata (Coleoptera: Buprestidae) في حدائق الموالح في مصر

صلاح محروس هاشم ، راضي محمدي عبد المعطي و انطون ولسن تادرس معهد بحوث وقاية النباتات- مركز البحوث الزراعية - الجيزة- مصر.

تم دراسة معدل الإصابة (النسبة المئوية لعدد الأشجار المصابة) ودرجة الإصابة (عدد

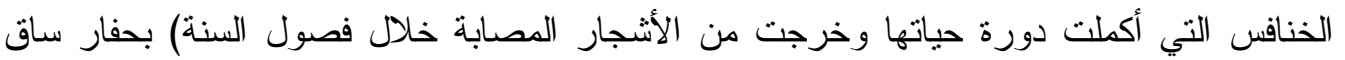

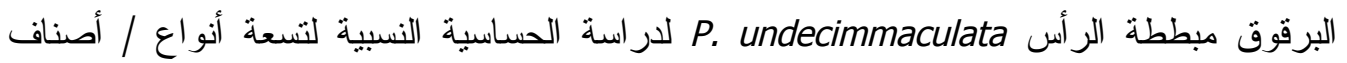
محلية أو أجنبية مستوطنة ومنتشرة في مصر حاليا في حدائق الموالح (الحمضيات) و هي البرتقال


و الجريب فروت Grape fruit، و اليوسفي البلدي Mandarin، و الليمون البلدي البنزهير Lime، والبكا،

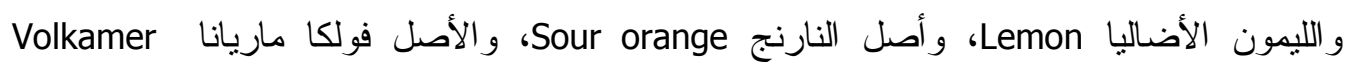

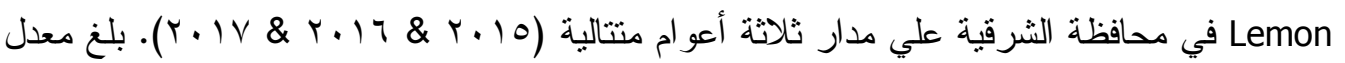

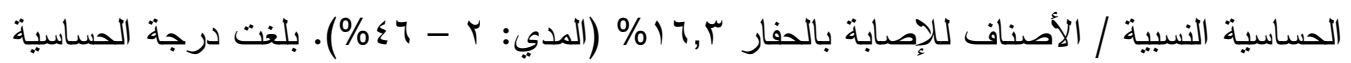

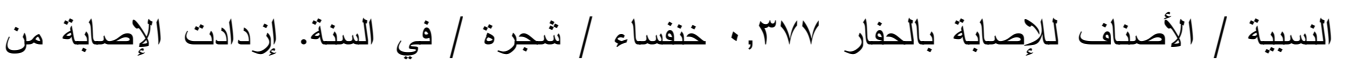

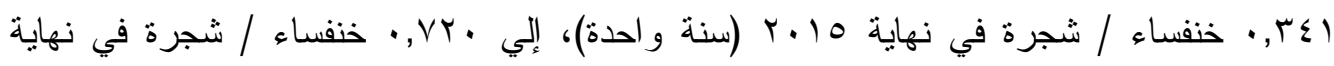

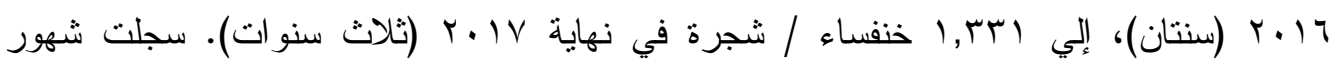

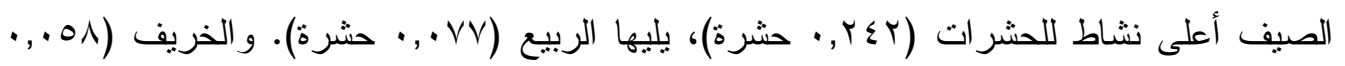

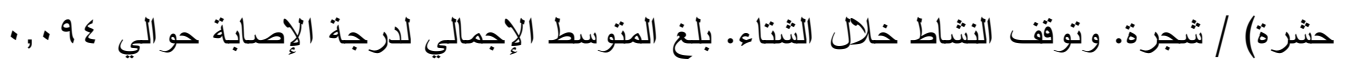

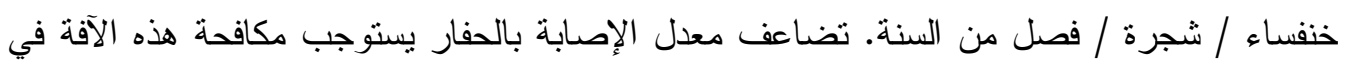
حدائق الموالح. وفي جميع الأحوال كان البرتقال بسرة أكثر حساسية للإصابة (1\% (9,1))، يليه

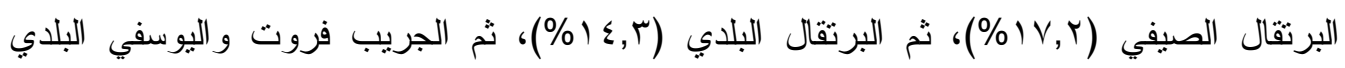

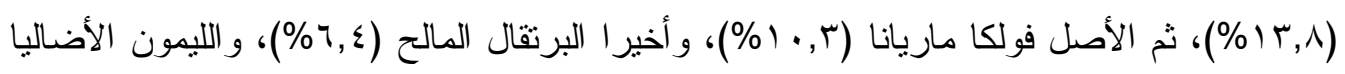

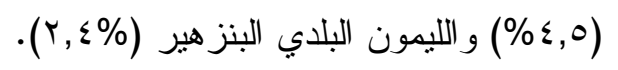


